\title{
Secretoneurin Induces Airway Mucus Hypersecretion by Enhancing the Binding of EGF to NRP1
}

\author{
Rui Xua Qi Lia Jia Zhou ${ }^{b}$ Xiangdong Zhou ${ }^{a}$ Juliy M. Perelman ${ }^{c}$ Victor P. Kolosov \\ aDepartment of Respiratory Medicine, the Second Affiliated Hospital, Chongqing Medical University, \\ bDepartment of Respiratory Medicine, the First Affiliated Hospital, Chongqing Medical University, \\ Chongqing, China; 'Far Eastern Scientific Center of Physiology and Pathology of Respiration, Russian \\ Academy of Medical Sciences, Blagoveschensk, Russia
}

\section{Key Words}

Secretoneurin - Airway mucus hypersecretion - Mucin5AC $\cdot$ Signaling pathway

\begin{abstract}
Aims: Secretoneurin(SN), a neuropeptide, has been considered a reliable marker of allergenic stimulation. However, the relationship between $\mathrm{SN}$ and the secretion of airway mucin remains unclear. In this study, we aimed to examine the in vitro relationship between SN and airway mucin over synthesis, as well as the signaling pathways involved. Methods and Results: Exogenous SN was added to two human airway epithelial cell lines (16HBE and NCI-H292). Measured by real-time quantitative polymerase chain reaction (qPCR) and enzyme-linked immuno sorbent assay (ELISA) respectively, the intracellular mucin(MUC)5AC mRNA and MUC5AC protein of culture supernates exhibited a time- and dose-dependent increase after stimulation of SN. Based on the evidence of an increased phosphorylation of ERK1/2 induced by exogenous $\mathrm{SN}$, we performed the radioactive binding assay. We failed to find direct binding of SN to either epidermal growth factor receptor (EGFR) or Neuropilin-1(NRP1), the co-receptor of EGFR. But we detected an enhanced binding of EGF to NRP1 in the two airway epithelial cell lines induced by exogenous SN. Either EGF neutralizing antibody or MEK specific inhibitor (PD-98059) could attenuate the over synthesis of MUC5AC induced by exogenous $\mathrm{SN}$, indicating an endogenous EGF dependent mechanism in MUC5AC over synthesis induced by SN. Conclusions: We conclude that SN induces MUC5AC hypersecretion in a dose- and time-dependent manner; moreover, the MUC5AC over synthesis induced by SN is strongly associated with the enhanced binding of EGF to NRP1 and the activation of EGFR and ERK1/2 subsequently.
\end{abstract}


Xu et al.: Secretoneurin Induces Airway Mucus Hypersecretion

\section{Introduction}

Normal airway mucus and mucociliary clearance are essential for innate lung defenses. The normally secreted quantity of airway mucus maintains airway hydration and traps particulates and pathogenic microorganisms. However, the overexpression of gel-forming mucus is a hallmark of several chronic pulmonary inflammatory diseases, such as chronic obstructive pulmonary disease (COPD), asthma, and cystic fibrosis [1, 2]. Excessive sputum overwhelms ciliary clearance and obstructs the airway, causing morbidity and mortality in patients with chronic inflammatory lung diseases. The secreted gel-forming mucins, mainly mucin5AC (MUC5AC), are expressed in the goblet cells. In chronic inflammatory airway diseases, MUC5AC expression is increased [3]. Investigations in mouse models have shown that MUC5AC expression is a hallmark of goblet-cell metaplasia. MUC5AC becomes one of the most intensively studied MUC genes in evaluations of airway mucin gene regulation and mucin glycoprotein secretion.

Secretoneurin (SN) is a neuropeptide that exhibits a moderate level of evolutionary conservation. SN arises from the proteolytic processing of secretogranin-II (SgII, also called chromogranin C). In the brain, $89-97 \%$ of the SgII precursor is processed to SN; $49 \%$ is cleaved in the adrenal medulla, and only $26 \%$ is processed in the anteriorpituitary [4]. Early research in mammalian systems revealed a relationship between SN and the secretion of follicle-stimulating hormone (FSH), growth hormone $(\mathrm{GH})$, prolactin (PRL), thyroid-stimulating hormone (TSH) and adrenocorticotropic hormone (ACTH) $[5,6]$. Studies in a goldfish model demonstrated that SN has neuroendocrine and paracrine effects that stimulate LH secretion and production in pituitary cells [7]. In addition to its association with the secretion of several endocrine hormones, $\mathrm{SN}$ has been demonstrated be responsible for neurofilament immunoreactions. Its reactions with different immune cells, such as monocytes, neutrophils, dendritic cells, and eosinophils, indicate that SN is a novel neuropeptide related to non-nervous inflammation [8]. According to immunohistochemical analyses, a large number of SN-positive neurocytes are present in allergic rhinitis. In addition, based on evidence that SN produces a significant increase in nasal lavage fluid in seasonal allergic rhinitis patients after contact with allergens [9], SN has been considered a reliable marker of allergenic stimulation. However, the relationship between SN and the secretion of airway mucin remains unclear. Furthermore, the specific cell-surface receptor for SN is also unclear, although there is sufficient evidence to support the hypothesis that a G-proteincoupled receptor is involved [10-12]. Research has indicated that SN stimulates increases in intercellular calcium and activates both cAMP production and ERK-dependent pathways in L $\beta \mathrm{T} 2$ cells $[13,14]$. Therefore, we investigated the relationship between SN and airway MUC5AC synthesis in vitro. Moreover, we evaluated the specific mechanisms of increased MUC5AC synthesis in human bronchial epithelial cells induced by SN.

\section{Materials and Methods}

\section{Cells, reagents and antibodies}

16HBE, a SV-40 virus-transformed, immortalized human bronchial epithelial cell line, was purchased from the Guangzhou Respiratory Institute (Guangzhou, China). Human lung epithelial cell line NCI-H292 cells were purchased from American Type Culture Collection (Manassas, VA, USA). Roswell Park Memorial Institute (RPMI) 1640 medium and fetal bovine serum (FBS) were purchased from Life Technologies (Grand Island, NY, USA). Primary antibodies, including mouse anti-human mucin5AC, rabbit anti-human ERK1/2, rabbit anti-human phosphorylated ERK1/2, rabbit anti-human EGFR, and rabbit anti-human phosphorylated EGFR were purchased from Abcam (Cambridge, MA, USA). A primary antibody against betaactin and secondary antibodies were purchased from Bioss (Beijing, China). The neutralizing antibodies of EGF and SN (EGF-Ab and SN-Ab) were purchased from Sigma-Aldrich (Shanghai, China). The MEK inhibitor PD-98059 was supplied by Cell Signaling Technology (Danvers, MA, USA). Human SN was obtained from United States Biological (Swampscott, MA, USA). Radioactive labeled SN and EGF ( ${ }^{125}$ I-SN and ${ }^{125}$ I-EGF) for 
Xu et al.: Secretoneurin Induces Airway Mucus Hypersecretion

Table 1. Primers for real-time qPCR

\begin{tabular}{lllc}
\hline Gene & Sense $\left(5^{\prime}-3^{\prime}\right)$ & Antisense(5'-3') & Product size (bp) \\
\hline MUC5AC & CACTCTACCACTCCCTGCTTC & CTTGACTAACCCTCTTGACCAC & 145 \\
GAPDH & CATCAAGAAGGTGGTGAAGCA & TCAAAGGTGGAGGAGTGGGT & 117 \\
\hline
\end{tabular}

radioactive binding assay were designed by PerkinElmer (Waltham, Massachusetts, USA).

\section{Cell culture and treatment}

The 16HBE and NCI-H292 cell lines were propagated in RPMI1640 supplemented with 10\% FBS, 100 $\mathrm{U} / \mathrm{ml}$ penicillin and $100 \mathrm{\mu g} / \mathrm{ml}$ streptomycin in a $37^{\circ} \mathrm{C} 5 \% \mathrm{CO}_{2}$ incubator respectively. Before additional treatments, cells were plated in $6 \times 60 \mathrm{~mm}$ culture dishes at a density of $2 \times 10^{6} / \mathrm{ml}$ and were cultured in a $37^{\circ} \mathrm{C}, 5 \% \mathrm{CO}_{2}$ incubator until the cells reached confluence. After serum starvation for $12 \mathrm{~h}$, cells were treated with SN at different concentrations $(0 \mathrm{ng} / \mathrm{ml}, 15 \mathrm{ng} / \mathrm{ml}, 60 \mathrm{ng} / \mathrm{ml}$, or $240 \mathrm{ng} / \mathrm{ml})$ for $24 \mathrm{~h}$ or with $240 \mathrm{ng} / \mathrm{ml}$ SN for different durations ( $0 \mathrm{~h}, 6 \mathrm{~h}, 12 \mathrm{~h}, 24 \mathrm{~h}$, or $48 \mathrm{~h})$. Before the subsequent tests, the MTT assay was used to evaluate the viability of the $16 \mathrm{HBE}$ cells. The following experiments were performed on cultures with $>95 \%$ viable cells.

To investigate the signaling cascade that mediates the SN-induced MUC5AC hypersecretion, cells

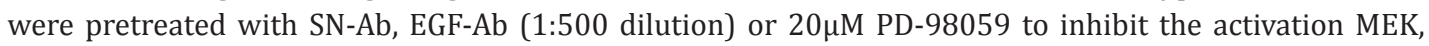
respectively [15]. Following a $24-\mathrm{h}$ incubation in a culture medium containing $240 \mathrm{ng} / \mathrm{ml} \mathrm{SN}$, the cells and culture supernatants were harvested for further analysis.

\section{Real-time quantitative PCR to assess MUC5AC gene transcription}

Briefly, total RNA was isolated using the RNAiso Plus RNA extraction solution (TaKaRa, Dalian, China). One-step RT-qPCR was performed to detect MUC5ACmRNA with the One-Step SYBR PrimeScript RT-PCR Kit (RR066A, TaKaRa, Dalian, China) according to the manufacturer's protocol. Glyceraldehyde-3-phosphate dehydrogenase (GAPDH) mRNA was used as an internal control for MUC5AC mRNA. The primers used for the real-time PCR amplification of MUC5AC mRNA and GAPDH mRNA are listed in Table 1. The relative mRNA expression levels were determined using the $\Delta \Delta \mathrm{Ct}$ method.

\section{Western blot analysis}

The expression of the p-ERK protein and p-EGFR in each treatment group were detected by western blotting. The 16HBE cells were washed with ice-cold PBS 3 times and were lysed on ice for 20 minutes using a western cell lysis buffer (Beyotime, Shanghai, China) containing PMSF, protease inhibitors, and phosphatase inhibitors. The lysis products were centrifuged at $12,000 \mathrm{rpm}$ for 15 minutes at $4^{\circ} \mathrm{C}$. The supernatants were standardized for equal protein concentration using the instructions in the BCA Protein Assay Kit (Beyotime, Shanghai, China). The samples were then mixed with loading buffer and were boiled in water for 10 minutes. After separation by sodium dodecyl sulfate polyacrylamide gel electrophoresis, the proteins were transferred onto polyvinylidene difluoride (PVDF) membranes. The PVDF membranes were blocked in 5\% BSA and were incubated with primary antibodies (anti-human ERK1/2 antibody, anti-human phosphorylated ERK1/2 antibody, anti-human EGFR antibody, anti-human phosphorylated EGFR antibody) at a 1:1000 dilution overnight at room temperature. After washing with PBST 3 times for 15 minutes, the PVDF membranes were incubated with the second antibody, goat anti-rabbit IgG (HRP), at a 1:3000 dilution for $2 \mathrm{~h}$. The blots were visualized using enhanced chemiluminescence following the protocol of the manufacturer of the reagent kit (KeyGen, Nanjing, China). The intensity of each band was measured using the Fluor-S MultiImager and QuantityOne software (Bio-Rad, Hercules, CA, USA).

\section{Enzyme-linked immunosorbent assay for MUC5AC in the cell supernatant}

The secreted MUC5AC in the cell culture supernatant was assessed by ELISA. The culture supernatants ( $50 \mu \mathrm{l}$ per well) were added to a 96 -well plate and were incubated at $37^{\circ} \mathrm{C}$ overnight until dry. After the wells were washed and blocked, they were incubated with the mouse monoclonal anti-MUC5AC antibody (1:200 dilution) for $2 \mathrm{~h}$. The plates were washed 3 times with PBST and were then incubated with $100 \mu \mathrm{l} /$ well goat anti-mouse IgG-HRP conjugate (1:3,000 dilution). After one hour, the plates were washed three times 
Xu et al.: Secretoneurin Induces Airway Mucus Hypersecretion

with PBST. The reaction was developed with 3, 3', 5, 5'-tetramethylbenzidine at room temperature and was stopped with $\mathrm{H}_{2} \mathrm{SO}_{4}$. The absorbance at $450 \mathrm{~nm}$ was measured, and the results were expressed as the ratio of MUC5AC to the standard.

125I- EGF-binding assays on airway epithelial cell lines

For binding assays 16HBE and NCI-H292 cells were cultured respectively in 24-well plates and washed twice with ice cold PBS. Cells were then incubated with $10 \mathrm{ng} / \mathrm{ml}^{125} \mathrm{I}$-EGF + SN $(0,30,60,120,180$, or $240 \mathrm{ng} / \mathrm{ml}$ ) at $4^{\circ} \mathrm{C}$ for 2 hours in RPMI1640. After washed 3 times with ice cold PBS (containing 1\% BSA), cells were lysed with $500 \mu \mathrm{l}$ cold PBS containing 1\% Triton X-100. $300 \mu \mathrm{l}$ of each sample were transferred to radio-immuno tubes and measured with a $\gamma$-counter (Perkin Elmer). Data were analyzed using GraphPad Prism 5.0.

\section{I- EGF binding assay}

Maxisorb tubes were coated with $100 \mu$ l recombinant human EGFR or NRP1 over night at $4^{\circ} \mathrm{C}$ refrigerator. After 3 times washing with 350 $\mu$ l PBST (PBS containing 0.1\% Tween20), tubes were then blocked with $1 \%$ BSA $(150 \mu \mathrm{l})$ for 1 hour at room temperature and washed again 3 times with PBST. Then $50 \mathrm{cpm}^{125} \mathrm{I}$-EGF in $50 \mu \mathrm{l}$ PBS containing $1 \%$ BSA and 0 to $240 \mathrm{ng} / \mathrm{ml}(0,0,30,60,120,180$, or $240 \mathrm{ng} / \mathrm{ml}) \mathrm{SN}$ was added to the Maxisorb tubes and allowed to incubate for 2 hours at room temperature. After washed with PBST for 3 times, tubes were then counted in a $\gamma$-counter.

\section{Cell immunochemistry and laser confocal microscopy}

The direct visual observation of the intracellular MUC5AC protein was performed using immunochemistry and laser confocal microscopy. Cells were plated at a density of $2 \times 10^{5} / \mathrm{ml}$ in 24 -well plates on a glass coverslip in each well. The cells were washed three times with PBS, fixed with $4 \%$ paraformaldehyde for 15 minutes, and washed again with PBS. The fixed 16HBE cells were permeabilized with $0.1 \%$ Triton X-100 in PBS for 10 minutes and were washed 3 times with PBS. The cells were then blocked in 5\% goat serum for 60 minutes and were incubated with mouse anti-MUC5AC (1:500 dilution) overnight. After 3 times washing with PBS, the slides were incubated for 60 minutes with the secondary antibody, FITC-linked goat anti-mouse IgG (1:200 dilution). After 3 times washing with PBS, the slides were incubated with $5 \%$ propidium iodide for $3 \mathrm{~min}$, washed with PBS 5 times and embedded in $50 \%$ glycerol. The 16HBE cells were visualized using a confocal microscope (TCS-SP2, Leica, Germany). Representative images were obtained with a digital camera and were then processed with Adobe Photoshop 7.0.

\section{Results}

Dose-response and time-course studies of the effect of SN on MUC5AC synthesis

The synthesis of MUC5AC mRNA exhibited a dose-dependent increase in response to SN stimulation for $24 \mathrm{~h}$. The levels of MUC5AC mRNA were increased by approximately 2.6 -fold in 16HBE cells and 3.3-fold in NCI-H292 cells in response to $60 \mathrm{ng} / \mathrm{ml}$ SN stimulation. MUC5AC mRNA levels were increased by 3.9-fold in 16HBE cells and 4.7-fold in NCI-H292 cells in response to $240 \mathrm{ng} / \mathrm{ml}$ SN stimulation respectively, compared to timematched controls. However, $15 \mathrm{ng} / \mathrm{ml} \mathrm{SN}$ failed to induce a significant increase in MUC5AC transcription in either $16 \mathrm{HBE}$ or NCI-H292 cells compared to the untreated control (Fig. 1a). The levels of MUC5AC protein secreted in the cell culture supernatant were determined by ELISA. Stimulation with $60 \mathrm{ng} / \mathrm{ml} \mathrm{SN}$ induced approximately 2.3 -fold increases in $16 \mathrm{HBE}$ cells and 3.6-fold increases in NCI-H292 cells respectively, in the MUC5AC protein in the culture supernatant. While $240 \mathrm{ng} / \mathrm{ml}$ SN induced higher increases of MUC5AC protein in the culture supernatant, at about 3.6-fold increase in 16HBE cells and 4.6-fold in NCI-H292 cells (Fig. 1b). To further investigate the time course of MUC5AC induction by SN stimulation, $16 \mathrm{HBE}$ cells and NCI-H292 cells were treated with $240 \mathrm{ng} / \mathrm{ml} \mathrm{SN}$ for different durations (0 h, $6 \mathrm{~h}, 12 \mathrm{~h}, 24 \mathrm{~h}$, and $48 \mathrm{~h}$ ). Compared to the baseline, the levels of MUC5AC mRNA and protein in the culture supernatant increased beginning at approximately $6 \mathrm{~h}$ and peaked at approximately $24 \mathrm{~h}$ (Fig. 1c, d). 


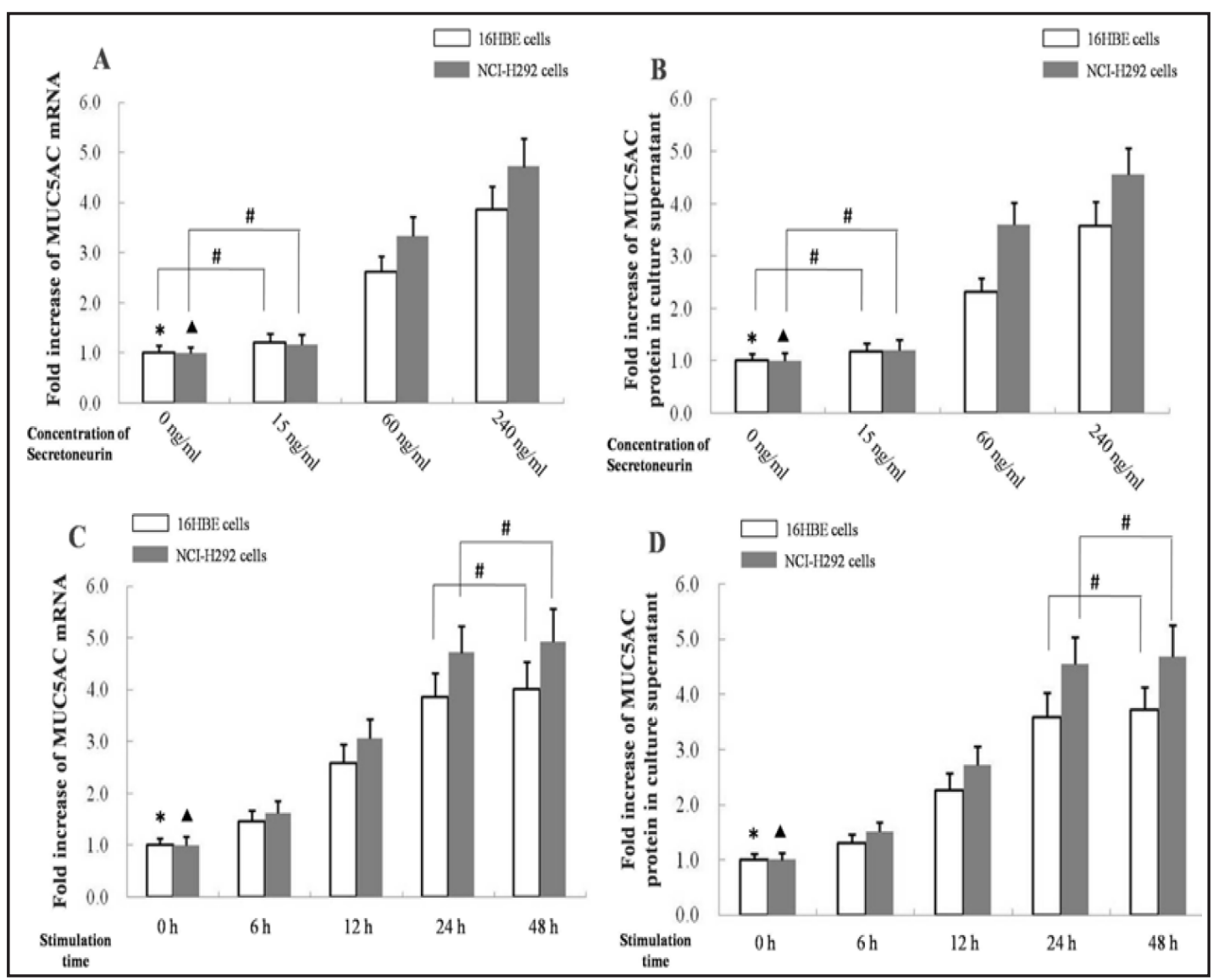

Fig. 1. The changes of MUC5AC in $16 \mathrm{HBE}$ cells and NCI-H292 cells induced by SN stimulation were timeand dose-dependent. (A) The fold increases in the cellular MUC5AC mRNA levels and (B)in the cell culture supernatant MUC5AC protein levels at $24 \mathrm{~h}$ in response to different concentrations of SN. Cells exposed to SNfree RPMI1640 were used as negative controls. ${ }^{*} P<0.05$ (vs. $16 \mathrm{HBE}$ cells stimulated by $60 \mathrm{ng} / \mathrm{ml}$ or $240 \mathrm{ng} /$ $\mathrm{ml} \mathrm{SN}$ ); ${ }^{\wedge} P<0.05$ (vs. NCI-H292 cells stimulated by $60 \mathrm{ng} / \mathrm{ml}$ or $240 \mathrm{ng} / \mathrm{ml} \mathrm{SN}$ ); ${ }^{\#} P>0.05$ (between groups); $n=6$. (C) The fold increases in the cellular MUC5AC mRNA levels and (D) in the cell culture supernatant MUC5AC protein levels in response to different durations of exposure to $240 \mathrm{ng} / \mathrm{ml}$ SN. Cells exposed to SN-free RPMI1640 were used as negative controls. ${ }^{*} P<0.05$ (vs. $16 \mathrm{HBE}$ cells stimulated by $6 \mathrm{~h}, 12 \mathrm{~h}, 24 \mathrm{~h}$, and 48h); ${ }^{\wedge} P<0.05$ (vs. NCI-H292 cells stimulated by $6 \mathrm{~h}, 12 \mathrm{~h}, 24 \mathrm{~h}$, and $48 \mathrm{~h}$ ); ${ }^{\#} P>0.05$ (between groups); $\mathrm{n}=6$.

SN stimulates EGFR in 16HBE cells and NCI-H292 cells and subsequently activated ERK1/2-dependent pathway

As previous studies providing an intimate relationship between SN and the activation of MAPK family members, especially ERK1/2 $[13,16]$, we detected the phosphorylation of ERK1/2 as well as EGFR, the main signaling receptor upstream of ERK1/2 in MUC5AC hypersecretion.

In vitro cellular studies, the activation of EGFR in both 16HBE and NCI-H292 cells by SN was detected by Western Blot. The phosphorylated EGFR showed a 3.61-fold increase in 16HBE cells and 3.21- fold increase in NCI-H292 cells, after 24 h stimulation by $240 \mathrm{ng} / \mathrm{ml}$ SN. In 16HBE and NCI-H292 cells, we found the activation of EGFR by SN could be partially inhibited by a neutralizing SN antibody (SN-Ab) (1:500, Sigma-Aldrich) (Fig. 2a).

Western blot analysis of phosphorylated ERK1/2 additionally showed an increase of SN (240ng/ml, $24 \mathrm{~h}$ ) induced activation of ERK1/2 in both 16HBE cells and NCI-H292 cells. SN induced the activation of ERK1/2 by 2.5 -fold in 16HBE cells and 2.1-fold in NCI-H292 cells. The SN-Ab attenuated the phosphorylation of ERK1/2 induced by SN (Fig. 2b). 
Fig. 2. Changes in the phosphorylation of EGFR (A) and ERK1/2 (B) in 16HBE and NCI-H292 cells induced by SN stimulation were measured by Western Blot. Cells were exposed to $240 \mathrm{ng} / \mathrm{ml} \mathrm{SN}$ or $240 \mathrm{ng} /$ $\mathrm{ml} \mathrm{SN} \mathrm{+} \mathrm{neutralizing} \mathrm{SN}$ antibody(SN-Ab) for 24 h. Cells exposed to SNfree RPMI1640 for $24 \mathrm{~h}$ were used as negative controls. ${ }^{*} P<0.05$ (vs. 16HBE control group and $\mathrm{SN}+\mathrm{SN}-\mathrm{Ab}$ group); $\triangle P<0.05$ (vs. NCI-H292 control group and $\mathrm{SN}+$ $\mathrm{SN}-\mathrm{Ab}$ group); $\mathrm{n}=6$.

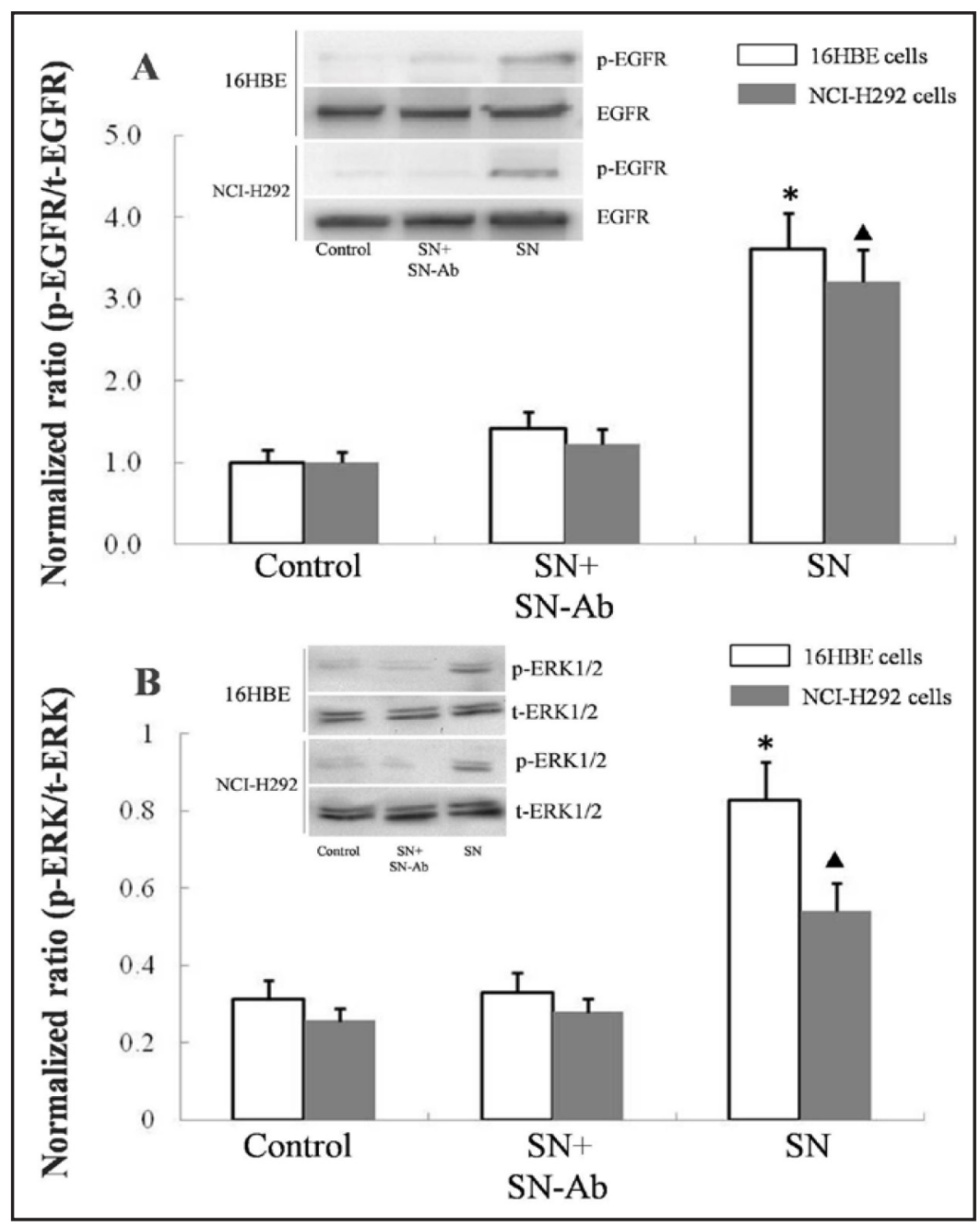

Secretoneurin Increases EGF Binding to Neuropilin-1 but not EGFR

To determine the specific mechanism of secretoneurin induced EGFR stimulation in airway epithelial cells, we designed a radioactive ${ }^{125}$ I labeled SN ${ }^{125}$ I-SN) and investigated whether SN might interact with EGFR or its co-receptor Neuropilin-1 (NRP1) [17]. However, we failed to find the direct binding of SN to either EGFR or NRP1 (data not shown). To determine the hypothesis that SN might influence the interaction between EGF and its receptor EGFR or NRP1, we designed radioactive ${ }^{125}$ I labeled EGF (125I-EGF) to perform the radioactive binding assay in vitro. Incubation with $60 \mathrm{ng} / \mathrm{ml} \mathrm{SN}$ resulted in increased binding of ${ }^{125} \mathrm{I}$-EGF to $16 \mathrm{HBE}$ cells and with a maximum effect at about $240 \mathrm{ng} / \mathrm{ml}$ SN. Same effect was found in NCI-H292 cells (Fig. 3a). On the basis of the increased affinity of EGF to 16HBE and NCI-H292 cells induced by SN, we performed further studies to ensure whether SN increased binding of EGF to EGFR. However, with increasing amounts of SN from 30ng/ $\mathrm{ml}$ to $240 \mathrm{ng} / \mathrm{ml}$, we failed to elicit an increased binding of EGF to EGFR (Fig. 3b). We further hypothesized that SN might stimulate binding of EGF to NRP1, the co-receptor of EGFR. To verifying the hypothesis, the binding assay between EGF and NRP1 was performed based on the radioactive labeled EGF, same as mentioned above. SN induced a significant increase (1.16- fold, $P<0.05$ vs. ${ }^{125}$ I-EGF) in ${ }^{125}$ I-EGF binding to NRP1 at a concentration of $60 \mathrm{ng} / \mathrm{ml}$, with a maximum effect at $180 \mathrm{ng} / \mathrm{ml}$ (1.47- fold, $P<0.05$ vs. ${ }^{125}$ I-EGF) in both $16 \mathrm{HBE}$ and NCI-H292 cell lines (Fig. 3c). 


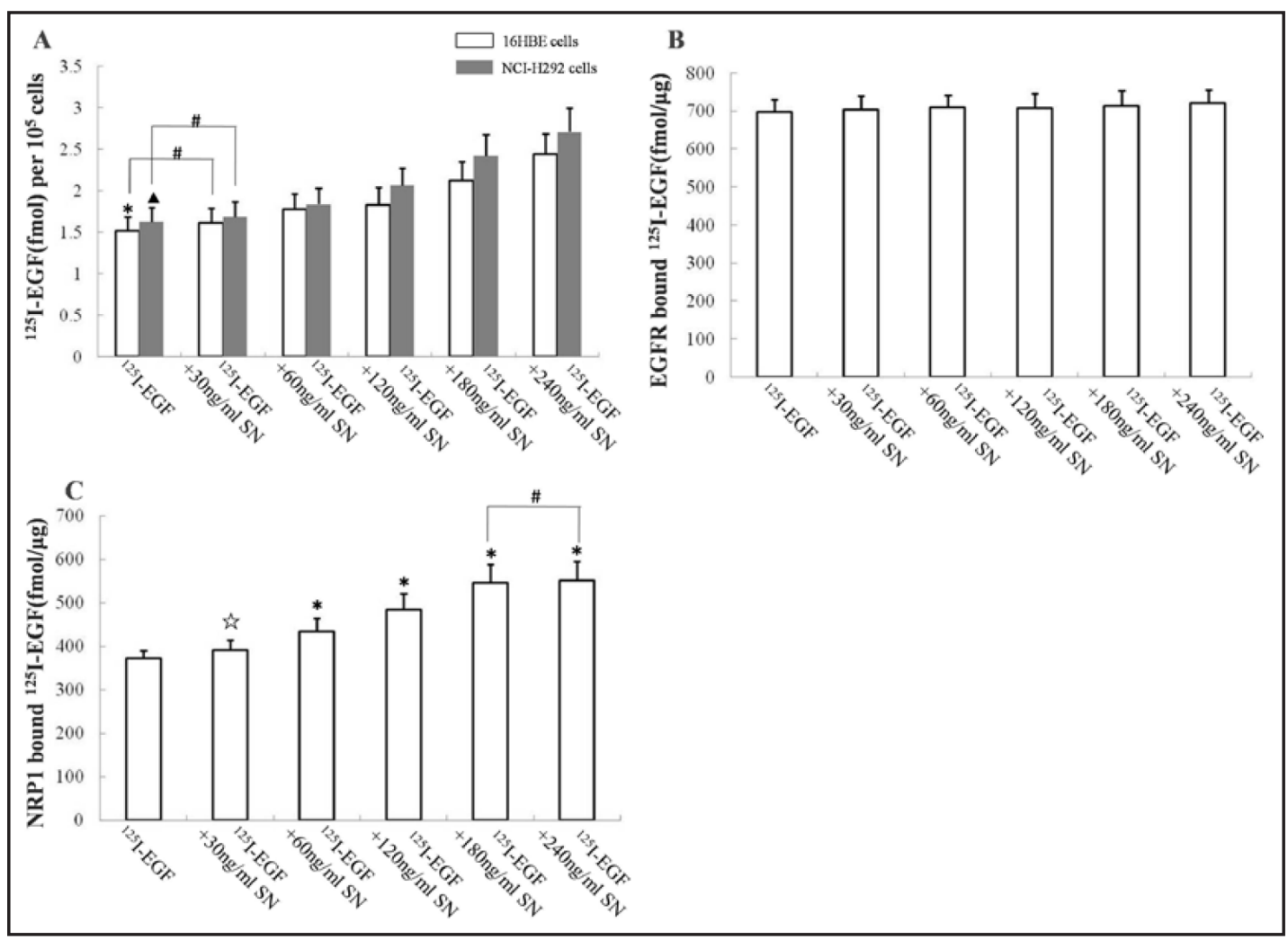

Fig. 3. SN stimulates the binding of EGF to NRP1 but not EGFR. (A) SN increases the binding of ${ }^{125}$ I-EGF to human airway epithelial cell lines, both $16 \mathrm{HBE}$ and NCI-H292. In the radioactive binding assays, $10 \mathrm{ng} / \mathrm{ml}$ ${ }^{125} \mathrm{I}$-EGF with the increasing amounts of SN $(0,30,60,120,180$ and $240 \mathrm{ng} / \mathrm{ml})$ was added to $16 \mathrm{HBE}$ or NCI$\mathrm{H} 292$ cell lines at $4^{\circ} \mathrm{C}$ for 2 hours. Binding of ${ }^{125} \mathrm{I}-\mathrm{EGF}$ was significantly increased in the presence of $60 \mathrm{ng} / \mathrm{ml}$ SN. ${ }^{*} P<0.05$ (vs. ${ }^{125} \mathrm{I}-\mathrm{EGF}+60 \mathrm{ng} / \mathrm{ml} \mathrm{SN},{ }^{125} \mathrm{I}-\mathrm{EGF}+120 \mathrm{ng} / \mathrm{ml} \mathrm{SN},{ }^{125} \mathrm{I}-\mathrm{EGF}+180 \mathrm{ng} / \mathrm{ml} \mathrm{SN}$, or ${ }^{125} \mathrm{I}-\mathrm{EGF}+240 \mathrm{ng} /$ $\mathrm{ml} \mathrm{SN}$ in 16HBE cells); ${ }^{\nabla} P<0.05$ (vs. ${ }^{125} \mathrm{I}-\mathrm{EGF}+60 \mathrm{ng} / \mathrm{ml} \mathrm{SN},{ }^{125} \mathrm{I}-\mathrm{EGF}+120 \mathrm{ng} / \mathrm{ml} \mathrm{SN},{ }^{125} \mathrm{I}-\mathrm{EGF}+180 \mathrm{ng} / \mathrm{ml} \mathrm{SN}$, or ${ }^{125} \mathrm{I}-\mathrm{EGF}+240 \mathrm{ng} / \mathrm{ml} \mathrm{SN}$ in NCI-H292 cells); ${ }^{*} P>0.05$ between groups; $\mathrm{n}=6$. (B) SN does not influence ${ }^{125} \mathrm{I}-\mathrm{EGF}$ binding to EGFR. Maxisorb tubes were coated with recombinant human EGFR, and binding assays in the presence of increasing amounts of SN from 0 to $240 \mathrm{ng} / \mathrm{ml}$ were performed. No significant difference was found between groups. (C) SN increases ${ }^{125}$ I-EGF binding to NRP1. Maxisorb tubes were coated with recombinant human NRP1, and binding assays in the presence of increasing amounts of SN from 0 to $240 \mathrm{ng} / \mathrm{ml}$ were performed. ${ }^{*} P<0.05$ (vs. ${ }^{125}$ I-EGF group); $P>0.05$ (vs. ${ }^{125}$ I-EGF group); ${ }^{\#} P>0.05$ between groups; $\mathrm{n}=6$.

The signaling pathway of SN induced MUC5AC over-synthesis in human airway epithelial cells

Based on evidence that SN enhanced EGF binding to NRP1 and induced the activation of EGFR, we investigated whether the activation of EGFR-MEK-ERK1/2 related signaling pathway was essential for the MUC5AC over-synthesis induced by SN. With prepared in serum-free and antibiotic-free RPMI 1640 for $12 \mathrm{~h}$, cells were then randomly divided into different experimental groups. Both 16HBE and NCI-H292 cells were pretreated with PD$98059(20 \mu \mathrm{M})$ to inhibit the activation of MEK (SN+PD-98059 group), co-incubated with 1:500 neutralizing SN antibody (SN+SN-Ab group) or 1:500 neutralizing EGF antibody (SN+EGF-Ab group) .Cells were stimulated with $240 \mathrm{ng} / \mathrm{ml} \mathrm{SN}$ for $24 \mathrm{~h}$. The levels of MUC5AC mRNA were assessed by real-time qPCR. The MUC5AC proteins in the cell supernatants were detected by ELISA. The intracellular MUC5AC proteins were visualized by cell immunochemistry, as described in the Materials and Methods section.

As demonstrated by real-time qPCR, $240 \mathrm{ng} / \mathrm{ml} \mathrm{SN}$ brought approximate 3.87-fold upregulation of MUC5AC in 16HBE cells and 4.72- fold in NCI-H292 cells. These effects again 


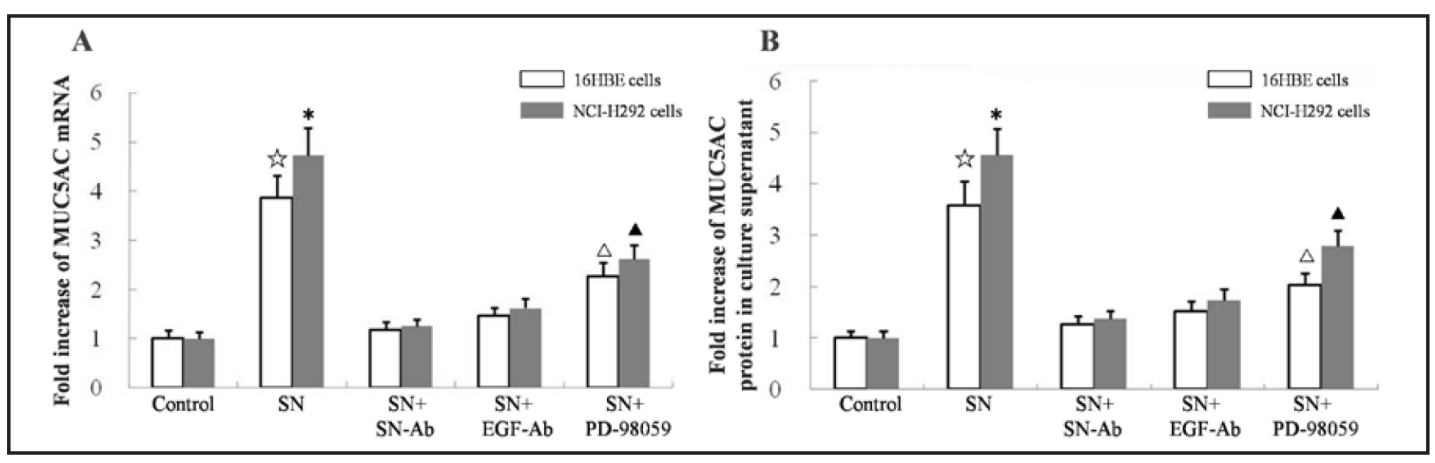

Fig. 4. Changes of MUC5AC in human airway epithelial cell lines induced by SN stimulation. (A) The fold increases in the cellular MUC5AC mRNA levels and (B) in the cell culture supernatant MUC5AC protein levels. Cells exposed to SN-free RPMI1640 for $24 \mathrm{~h}$ were set as negative controls. In SN group, cells were exposed to $240 \mathrm{ng} / \mathrm{ml} \mathrm{SN}$ for $24 \mathrm{~h}$. In SN+ SN-Ab group, cells were incubated with $240 \mathrm{ng} / \mathrm{ml} \mathrm{SN}$ and SN neutralizing antibody (1:500 dilution). In SN+ EGF-Ab group, cells were maintained in 240ng/ml SN and EGF neutralizing antibody (1:500 dilution). In SN+ PD-98059 group, cells were pretreated with 20 $\mu$ M PD-98059 for 1 $\mathrm{h}$, then exposed to $240 \mathrm{ng} / \mathrm{ml} \mathrm{SN}$ for $24 \mathrm{~h}$. ${ }^{\star} P<0.05$ (vs. other groups of $16 \mathrm{HBE}$ cell line); ${ }^{*}<<0.05$ (vs. other groups of NCI-H292 cell line); ${ }^{\wedge} P<0.05$ (vs. control group of $16 \mathrm{HBE}$ cell line); ${ }^{\wedge} P<0.05$ (vs. control group of NCI-H292 cell line), $n=6$.

Fig. 5. 16HBE cells were subjected to immunostaining for MUC5AC and were analyzed under a confocalmicroscope. The cell nuclei were visualized with $5 \%$ propidium iodide. Representative images of six independent experiments are shown. Original magnification, $\times 800$. Cells exposed to SN-free RPMI1640 for 24 $\mathrm{h}$ were set as negative controls. In $\mathrm{SN}$ group, cells were exposed to $240 \mathrm{ng} / \mathrm{ml} \mathrm{SN}$ for $24 \mathrm{~h}$. In $\mathrm{SN}+\mathrm{SN}-\mathrm{Ab}$ group, cells were incubated with $240 \mathrm{ng} / \mathrm{ml} \mathrm{SN}$ and SN neutralizing antibody (1:500 dilution). In SN+ EGF-Ab group, cells were maintained in 240ng/ $\mathrm{ml} \mathrm{SN}$ and EGF neutralizing antibody (1:500 dilution). In SN+ PD-
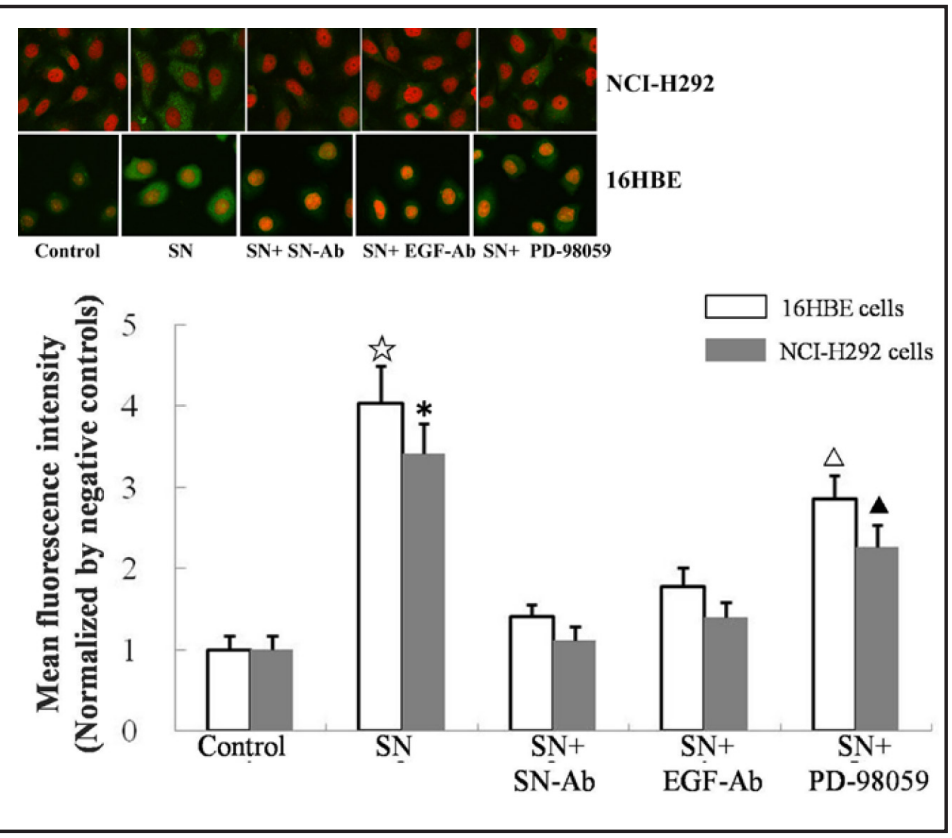
98059 group, cells were pretreated with $20 \mu \mathrm{M}$ PD-98059 for $1 \mathrm{~h}$, then exposed to $240 \mathrm{ng} / \mathrm{ml} \mathrm{SN}$ for $24 \mathrm{~h}$. ${ }^{\star} P<0.05$ (vs. other groups of $16 \mathrm{HBE}$ cell line); ${ }^{*} P<0.05$ (vs. other groups of NCI-H292 cell line); ${ }^{\triangle} P<0.05$ (vs. control group of $16 \mathrm{HBE}$ cell line); ${ }^{\wedge} P<0.05$ (vs. control group of NCI-H292 cell line), $\mathrm{n}=6$.

could be blocked by EGF-Ab (1:500 dilution) indicating that SN-induced MUC5AC oversynthesis depended on endogenous EGF (Fig. 4a).

To analyze the secreted MUC5AC protein levels, supernatants were collected from the 16HBE cells and were subjected to ELISA analysis. Both 16HBE and NCI-H292 cell lines were treated similarly as mentioned above. EGF-Ab (1:500 dilution) or PD-98059 significantly attenuated the hypersecretion of MUC5AC induced by SN (Fig. 4b). 
Furthermore, we visualized the MUC5AC protein in the 16HBE cells using cellular immunochemistry and laser confocal microscopy, as described in the Materials and Methods section. The intracytoplasmic green fluorescence intensity of 16HBE and NCI-H292 cells reflected the concentration of the intracellular MUC5AC protein. Representative images were obtained, and the intracellular MUC5AC protein levels were normalized to those of the negative controls. The results indicated an approximately 4-fold increase in intracellular MUC5AC protein in 16HBE and NCI-H292 cell lines after SN stimulation. To further confirm the involvement of endogenic EGF and ERK1/2-associated pathways in the increased synthesis of MUC5AC induced by SN, we applied specific inhibitor of MEK (PD-98059), EGF$\mathrm{Ab}$ and $\mathrm{SN}-\mathrm{Ab}$ to block the activation of EGFR-ERK1/2 related pathway chain. Pretreatment with EGF-Ab, SN-Ab or PD-98059 attenuated the amplification of the intracellular MUC5AC protein levels induced by SN stimulation of 16HBE or NCI-H292 cells. This finding indicates a critical role for EGFR-ERK1/2 related signaling in MUC5AC over-expression in 16HBE cells stimulated with SN (Fig. 5).

\section{Discussion}

Secretoneurin is a neuropeptide that is responsible for the migration of inflammatory cells, such as eosinophils, monocytes, and dendritic cells. Previous studies of allergic diseases have explored the critic role of SN in therapid onset of several allergic diseases, such as allergic rhinitis and asthma. Secretoneurin-immunoreactive nerve fibers in the respiratory tract have been found to co-localize with vesicular acetylcholine transporters, tyrosine hydroxylase, calcitonin gene-related peptide, and vasoactive intestinal peptide, indicating that secretoneurin is localized to cholinergic, adrenergic, and sensory nerves. Immunohistochemical studies of mucosal biopsies and nasal lavage fluid have indicated a predominant distribution of SN around submucosal glands in the airways of patients with seasonal allergic rhinitis [9]. Allergen exposure or bronchial histamine challenge increases the sputum levels of secretoneurin [18]. Based on the evidence of the enhanced expression of secretoneurin by decreased oxygen levels, some researchers treated secretoneurin as a predictive marker for hypoxic injuries [19].

The remodeling of the airway epithelium to a secretory phenotype has been implicated in the pathophysiology of asthma and COPD [20]. Mucus hypersecretion is a major feature of inflammatory pulmonary diseases such as asthma, chronic bronchitis and cystic fibrosis. MUC5AC is recognized as one of the major components released by human airway epithelial cells. Neuropeptides such as substance P (SP), vasoactive intestinal peptide (VIP), and the tachykinin neurokinin A (NKA) are related to the hypersecretion of airway MUC5AC [20]. However, as a newly identified neuropeptide that has been partly described as a novel hormone [21],SN has an unclear relationship with MUC5AC synthesis.

In this study, we applied exogenous SN stimulation to 16HBE cells and revealed that SN produces a dose- and time-dependent upregulation of MUC5AC synthesis and secretion. Our data indicated that after approximately $24 \mathrm{~h}$ of stimulation with $240 \mathrm{ng} / \mathrm{ml}$ exogenous SN, MUC5AC mRNA and protein synthesis peaked at approximately 4 to 5-fold above the baseline levels. Although the SN receptor has not yet been isolated or unidentified, several lines of evidence in different cell types have indicated that the receptor for SN is a G-proteincoupled receptor that, upon binding to the substrate, activates cAMP production and an ERK-dependent pathway $[6,10-12]$. Because ERK1/2 acts as a major signaling pathway that regulates MUC5AC synthesis in human airway epithelial cells $[22,23]$, we also measured the activity of ERK1/2 in both NCI-H292 and 16HBE cell lines and confirmed that SN induced the enhancement of ERK1/2 phosphorylation. To fully understand the specific mechanisms in SN-induced MUC5AC hypersecretion, we designed a radioactive ${ }^{125}$ I labeled SN and investigated whether SN might interact with EGFR or its co-receptor NRP1. However, we failed to detect the direct binding of SN to either EGFR or NRP1. With radioactive ${ }^{125}$ I labeled EGF, we found an enhancement binding of EGF to NRP1 but not EGFR through the increased 
concentration of exogenous SN. Pretreatment with a neutralizing antibody of EGF partially blocked the enhancement synthesis of MUC5AC induced by exogenous SN indicating an endogenous EGF dependent mechanism.

In summary, this in vitro study provides evidence of a relationship between SN and airway mucin hypersecretion. The airway MUC5AC hypersecretion induced by SN appears to depend significantly on an ERK1/2-related signaling pathway by enhancing the binding of EGF to NRP1, the vital co-receptor of EGFR. These in vitro data, which confirm an association between the newly identified neuropeptide SN and the over-expression of airway MUC5AC, should encourage further exploration of the relationship between SN and acute episodes of seasonal asthma.

\section{Acknowledgments}

This work was supported by grants from the National Nature Science Foundation of China (no. 31171346) and the China-Russia Cooperation Research Foundation (no. 31211120168).

\section{Conflict of Interest}

The authors declare that they have no conflicts of interest.

\section{References}

1 Del Donno M, Bittesnich D, Chetta A, Olivieri D, Lopez-Vidriero MT: The effect of inflammation on mucociliary clearance in asthma: An overview. Chest 2000;118:1142-1149.

2 Maestrelli P, Saetta M, Mapp CE, Fabbri LM: Remodeling in response to infection and injury. Airway inflammation and hypersecretion of mucus in smoking subjects with chronic obstructive pulmonary disease. Am J Respir Crit Care Med 2001;164:S76-80.

3 Thai P, Loukoianov A, Wachi S, Wu R: Regulation of airway mucin gene expression. Annu Rev Physiol 2008;70:405-429.

4 Kirchmair R, Hogue-Angeletti R, Gutierrez J, Fischer-Colbrie R, Winkler H: Secretoneurin--a neuropeptide generated in brain, adrenal medulla and other endocrine tissues by proteolytic processing of secretogranin ii (chromogranin c). Neuroscience 1993;53:359-365.

5 Crawford JL, McNeilly AS: Co-localisation of gonadotrophins and granins in gonadotrophs at different stages of the oestrous cycle in sheep. J Endocrinol 2002;174:179-194.

-6 Fischer-Colbrie R, Laslop A, Kirchmair R: Secretogranin ii: Molecular properties, regulation of biosynthesis and processing to the neuropeptide secretoneurin. Prog Neurobiol 1995;46:49-70.

7 Zhao E, McNeilly JR, McNeilly AS, Fischer-Colbrie R, Basak A, Seong JY, Trudeau VL: Secretoneurin stimulates the production and release of luteinizing hormone in mouse $1\{$ beta\}t2 gonadotropin cells. Am J Physiol Endocrinol Metab 2011;301:E288-297.

-8 Dunzendorfer S, Schratzberger P, Reinisch N, Kahler CM, Wiedermann CJ: Secretoneurin, a novel neuropeptide, is a potent chemoattractant for human eosinophils. Blood 1998;91:1527-1532.

-9 Korsgren M, Erjefalt JS, Hinterholzl J, Fischer-Colbrie R, Emanuelsson CA, Andersson M, Persson CG, Mackay-Sim A, Sundler F, Greiff L: Neural expression and increased lavage fluid levels of secretoneurin in seasonal allergic rhinitis. Am J Respir Crit Care Med 2003;167:1504-1508.

10 Gasser MC, Berti I, Hauser KF, Fischer-Colbrie R, Saria A: Secretoneurin promotes pertussis toxin-sensitive neurite outgrowth in cerebellar granule cells. J Neurochem 2003;85:662-669.

11 Kong C, Gill BM, Rahimpour R, Xu L, Feldman RD, Xiao Q McDonald TJ, Taupenot L, Mahata SK, Singh B, O'Connor DT, Kelvin DJ: Secretoneurin and chemoattractant receptor interactions. J Neuroimmunol 1998;88:91-98. 


\section{Cellular Physiology $\quad$ Cell Physiol Biochem 2014;33:446-456 and Biochemistry \\ Xu et al.: Secretoneurin Induces Airway Mucus Hypersecretion}

12 Schratzberger P, Woll E, Reinisch N, Kahler CM, Wiedermann CJ: Secretoneurin-induced in vitro chemotaxis of human monocytes is inhibited by pertussis toxin and an inhibitor of protein kinase c. Neurosci Lett 1996;214:208-210.

13 Zhao E, Basak A, Wong AO, Ko W, Chen A, Lopez GC, Grey CL, Canosa LF, Somoza GM, Chang JP, Trudeau VL: The secretogranin ii-derived peptide secretoneurin stimulates luteinizing hormone secretion from gonadotrophs. Endocrinology 2009;150:2273-2282.

14 Zhao E, Hu H, Trudeau VL: Secretoneurin as a hormone regulator in the pituitary. Regul Pept 2010;165:117-122.

15 Alessi DR, Cuenda A, Cohen P, Dudley DT, Saltiel AR: Pd 098059 is a specific inhibitor of the activation of mitogen-activated protein kinase kinase in vitro and in vivo. J Biol Chem 1995;270:27489-27494.

16 Yan S, Wang X, Chai H, Wang H, Yao Q, Chen C: Secretoneurin increases monolayer permeability in human coronary artery endothelial cells. Surgery 2006;140:243-251.

17 Rizzolio S, Rabinowicz N, Rainero E, Lanzetti L, Serini G, Norman J, Neufeld G, Tamagnone L: Neuropilin-1dependent regulation of egf-receptor signaling. Cancer Res 2012;72:5801-5811.

18 Korsgren M, Fischer-Colbrie R, Andersson M, Coman WB, Mackay-Sim A, Persson CG, Sundler F, Wallwork $\mathrm{B}$, Greiff L: Secretoneurin is released into human airways by topical histamine but not capsaicin. Allergy 2005;60:459-463.

19 Egger M, Schgoer W, Beer AG, Jeschke J, Leierer J, Theurl M, Frauscher S, Tepper OM, Niederwanger A, Ritsch A, Kearney M, Wanschitz J, Gurtner GC, Fischer-Colbrie R, Weiss G, Piza-Katzer H, Losordo DW, Patsch JR, Schratzberger P, Kirchmair R: Hypoxia up-regulates the angiogenic cytokine secretoneurin via an hif-1alpha- and basic fgf-dependent pathway in muscle cells. FASEB J 2007;21:2906-2917.

20 Davies DE: The role of the epithelium in airway remodeling in asthma. Proc Am Thorac Soc 2009;6:678682.

-21 Trudeau VL, Martyniuk CJ, Zhao E, Hu H, Volkoff H, Decatur WA, Basak A: Is secretoneurin a new hormone? Gen Comp Endocrinol 2012;175:10-18.

22 Song JS, Cho KS, Yoon HK, Moon HS, Park SH: Neutrophil elastase causes muc5ac mucin synthesis via egf receptor, erk and nf-kb pathways in a549 cells. Korean J Intern Med 2005;20:275-283.

-23 Lim JH, Kim HJ, Komatsu K, Ha U, Huang Y, Jono H, Kweon SM, Lee J, Xu X, Zhang GS, Shen H, Kai H, Zhang W, $\mathrm{Xu}$ H, Li JD: Differential regulation of streptococcus pneumoniae-induced human muc5ac mucin expression through distinct mapk pathways. Am J Transl Res 2009;1:300-311. 